\title{
Covid-19: NHS bosses told to assess risk to ethnic minority staff who may be at greater risk
}

\author{
Gareth lacobucci
}

The BMJ

NHS leaders in England have been told to "risk-assess" and make "appropriate arrangements" to protect ethnic minority staff who may be at a greater risk of covid-19.

The advice was issued in a letter from NHS England's chief executive, Simon Stevens, and chief operating officer, Amanda Pritchard, setting out actions for health bosses to take in the next phase of the service's response to the pandemic.

NHS England said that the advice was being issued "on a precautionary basis" while Public Health England investigated why the virus seemed to be having a disproportionate effect on healthcare workers from ethnic minority groups. ${ }^{2}$

Last week an analysis of the deaths of 106 healthcare workers published in $H S J$ found that $63 \%$ were from an ethnic minority background. $^{3}$

The BMA had called for the NHS to direct all providers to risk assess staff who were at greatest risk, such as those from ethnic minorities. But Chaand Nagpaul, chair of the BMA council, said that NHS England needed to go further than the letter by issuing more detailed guidance on how to carry out risk assessments.

He said, "The letter makes no mention of how providers should assess risk, and the BMA has already called on NHS England to develop a national risk assessment framework so that this can be done with objectivity and consistency across the NHS. This would take into account ethnicity, age, sex, and other medical conditions, as well as nature of work, risk of exposure, and other factors. Those at highest risk should be protected from working in infectious areas and redeployed to non-covid care or work remotely."

Meanwhile, the British International Doctors' Association has written to chief executives of all NHS trusts and health boards in the UK, ${ }^{4}$ urging them to follow the example of Somerset NHS Foundation Trust, which was the first in the country to include all ethnic minority staff in the vulnerable and at risk group and is encouraging them to discuss their concerns with managers. ${ }^{5}$

The association's letter says, "The steps to support BAME [black, Asian, and minority ethnic] staff could include: ensuring all BAME staff are allowed to wear [an] FFP3 mask in every area of the hospital; addressing and alleviating the anxieties that they may have following this $[H S J]$ study - this may involve reassuring or redeploying them wherever possible; prioritizing testing for them and their families; ensuring any covid-19 sickness absence does not have any deleterious impact on them financially or on their career progression."

1 NHS England. Coronavirus: second phase of NHS response to COVID-19. 29 Apr 2020. https://www.england.nhs.uk/coronavirus/publication/second-phase-of-nhs-response-tocovid-19-letter-from-simon-stevens-and-amanda-pritchard.

2 Rimmer A. Covid-19: Disproportionate impact on ethnic minority healthcare workers will be explored by government. BMJ 2020;369:m1562. 10.1136/bmj.m1562 32303494

Rimmer A. Covid-19: Two thirds of healthcare workers who have died were from ethnic minorities. BMJ 2020;369:m1621. 10.1136/bmj.m1621 32327412

4 British International Doctors' Association. Support for BAME health care workers. 28 Apr 2020. http://www.bidaonline.co.uk/wp-content/uploads/2020/04/BIDA-Letter-to-UK-Trustsand-Health-Boards-1-1.pdf.

5 Somerset NHS Foundation Trust. Supporting our BAME colleagues. 24 Apr 2020. https: //somersett.nhs.uk/?news=supporting-our-bame-colleagues.

Published by the BMJ Publishing Group Limited. For permission to use (where not already granted under a licence) please go to http://group.bmj.com/group/rights-licensing/ permissions 